\title{
DECISION SUPPORT SYSTEM OF EMPLOYEE ELECTION RECOMMENDATION ACCORDING TO PERSONALITY USING PROFILE MATCHING METHOD
}

\author{
Irwan Manuela Dwiyanto \\ Budi luhur University \\ Jakarta, Indonesia \\ irwanmanuela01@gmail.com
}

\author{
Agung Surya Kristanto \\ Budi luhur University \\ Jakarta, Indonesia
}
Motika Dian Anggraeni
Budi luhur University
Jakarta, Indonesia
Julaiha Probo Anggraini
Budi luhur University
Jakarta, Indonesia

\author{
DOI: $10.31364 / \mathrm{SCIRJ} / \mathrm{v} 7 . \mathrm{i} 1.2019 . \mathrm{P} 0119608$ \\ http://dx.doi.org/10.31364/SCIRJ/v7.i1.2019.P0119608
}

\begin{abstract}
In the current era of globalization, finding employees is no longer an easy thing. Strict competition makes each individual try to improve their quality. Especially in the search process of candidates, where in looking for candidates is not easy and often there is an error in the search process of the candidate itself if only relying on curriculum vitae. Therefore, personality is very necessary in dealing with the world of work, therefore the author wants to make an application of a decision support system that can adjust the criteria desired by the candidates who tested the accuracy by using the profile matching method. The results of this study are to add criteria other than curriculum vitae, namely the personality of candidates who are made based on the concept of knowledge management so that knowledge can be conveyed well to help job seekers in knowing their personality. After the application is finished, the writer does the test results of the system using the User Acceptance Test (UAT) method of $77 \%$ can be said to be good and can be applied in the candidate search process.
\end{abstract}

Keywords: Personality Test, Job Search, Knowledge Management, Profile matching, Job Vacancies.

\section{Introduction}

In Indonesia, finding employees is no longer an easy thing. Strict competition makes each individual try to improve their quality. The higher the level of education a person has, the wider the opportunity to get a job. However, in the eyes of a company title or title is not an absolute thing for someone in getting a job.

Future employment opportunities are also required for the competence of each job seeker, this is very important because the expertise possessed by individuals must be accountable and must master the field they are practicing. Professional people will be dynamic in enhancing their development because there are no rules that can hinder a person in a career, besides it requires someone to always be in a condition ready to accept all changes and develop to face the challenges ahead.

Having a degree and a high GPA is no longer a guarantee that someone will easily get a job. This is what sometimes becomes a dilemma for every student who is about to graduate, must have the desire to get a job that suits their knowledge when they are in college and their passion after they graduate. But sometimes dreams are not as beautiful as the reality. Limited job opportunities, high unemployment and lack of work experience they have caused them to not get the opportunity to get the job.

In fact, the world of work can trigger anxiety because job seekers will face competition in finding work, where there are many possibilities in it, such as getting a job or becoming unemployed. Especially if you look at developments that occur in the world of work today, where experience takes precedence. While the average college graduate has minimal work experience. 
Therefore, personality is indispensable in shaping passion to deal with the world of work. After the application is finished, the writer will do an analysis with profile matching method to find out whether the subject is suitable to work in that field.

\section{Theoretical Study}

\subsection{Definition of tests}

The test starts from a Latin language, namely testum. Which has the meaning of a soil measuring device. And in ancient French also has the meaning of size in distinguishing gold, silver and other metals. Testing is when taking a test, testee is a respondent who is working on a test while the tester is the subject of evaluation.

There are two kinds of functions that a test has in general, namely:

1. Is a measuring tool for students, where this test is closely related and functions in measuring the level of development and progress that has been achieved by students in the teaching-learning process that has been taken within a certain period.

2. Is a measure of success in the teaching program process, because through these tests can be analyzed about how far the teaching program can be achieved in the time and teaching that has been predetermined.

\subsection{Profile Matching}

This method is a profile matching method which is usually used in decision-making mechanisms where assuming an ideal level of ability that must be met by the subject under study. In profile matching it has a process which outlines the comparison process between competencies individually and with job or job competencies so that their compatibility is known. (Kusrini, 2007)

Profile Matching or matching method is a method to assist in making decisions. Where the assessment process is carried out by making a comparison between one profile with several other profile values, so that the results can be known the difference or difference in competency values from those needed. The difference in this method is called a gap, and the best or good value is a value that has a small or low gap.

Following this, the profile matching method has several stages and formulation of calculations:

\section{Weighting}

In the weighting process the thing done is to give weighting to each criterion and each aspect. The input value of this weighting process is the difference value from the expected value with the profile value. And in ranking all aspects both aspects of intellectual capacity, behavior, and work attitude at the same level of position in each gap. Then, given the weight value according to the table below

Table 2.1 Weight Description

\begin{tabular}{|c|c|c|l|}
\hline No. & Selisih Gap & Bobot Nilai & \multicolumn{1}{|c|}{ Keterangan } \\
\hline 1 & 0 & 5 & Kompetensi sesuai dengan yang dibutuhkan \\
\hline 2 & 1 & 4,5 & Kompetensi individu kelebihan 1 tingkat/level \\
\hline 3 & -1 & 4 & Kompetensi individu kurang 1 tingkat/level \\
\hline 4 & 2 & 3,5 & Kompetensi individu kelebihan 2 tingkat/level \\
\hline 5 & -2 & 3 & Kompetensi individu kurang 2 tingkat/level \\
\hline 6 & 3 & 2,5 & Kompetensi individu kelebihan 3 tingkat/level \\
\hline 7 & -3 & 2 & Kompetensi individu kurang 3 tingkat/level \\
\hline 8 & 4 & 1,5 & Kompetensi individu kelebihan 4 tingkat/level \\
\hline 9 & -4 & 1 & Kompetensi individu kurang 4 tingkat/level \\
\hline
\end{tabular}

\section{Core and Secondary Factor Grouping}

The next stage after the weighting process is to make groups from each criterion into two groups, namely core factors and secondary factors. 


\section{a. Core Factor (Main Factor)}

Core factors are aspects or competencies that are most needed by a position that can provide the most optimal performance results in accordance with estimates.

How to calculate the core factor formula can be used (Kusrini, 2007):

Description :

$$
\mathbf{N C F}=\frac{\sum \mathbf{N C}}{\sum \mathrm{IC}}
$$

$$
\begin{aligned}
\text { NCF } & =\text { Nilai rata-rata core factor } \\
\text { NC } & =\text { Total nilai core factor } \\
\text { IC } & =\text { Jumlah item core factor }
\end{aligned}
$$

a. Secondary Factor (Supporting factor)

Secondary factor is a supporting item in addition to the aspect that is owned by the core factor.

How to calculate the secondary factor can be used formula (Kusrini, 2007):

$$
\mathbf{N S F}=\frac{\sum \mathrm{NS}}{\sum \mathrm{IS}}
$$

Description :

$$
\begin{array}{ll}
\text { NSF } & =\text { Nilai rata-rata secondary factor } \\
\text { NS } & =\text { Total nilai secondary factor } \\
\text { IS } & =\text { Jumlah item secondary factor }
\end{array}
$$

The formula above is a formula used to calculate core and secondary factors based on aspects of work attitude and behavior. Formulas can also be used to calculate cores and secondary factors from aspects of intellectual capacity.

\section{Calculation of total value}

Based on the calculation of core factors and secondary factors of each aspect used, then the calculation of the total value of each aspect that affects the performance of each profile is calculated.

How to calculate the total value of each aspect, then use the formula (Kusrini, 2007)

$$
\mathrm{N}=(\mathrm{X}) \% \mathrm{NCF}+(\mathrm{X}) \% \mathrm{NSF}
$$

Description :

$\mathrm{N}=$ Total tiap aspek

$\mathrm{NCF}=$ Nilai rata-rata core factor

NSF = Nilai rata-rata secondary factor

$(\mathrm{X}) \%=$ Persentase yang diinputkan

\section{Ranking}

The result of the profile matching process is a ranking of each candidate submitted to fill a certain position / position. Determination refers to the ranking based on the results of calculations generated by the formula below (Kusrini, 2007): 

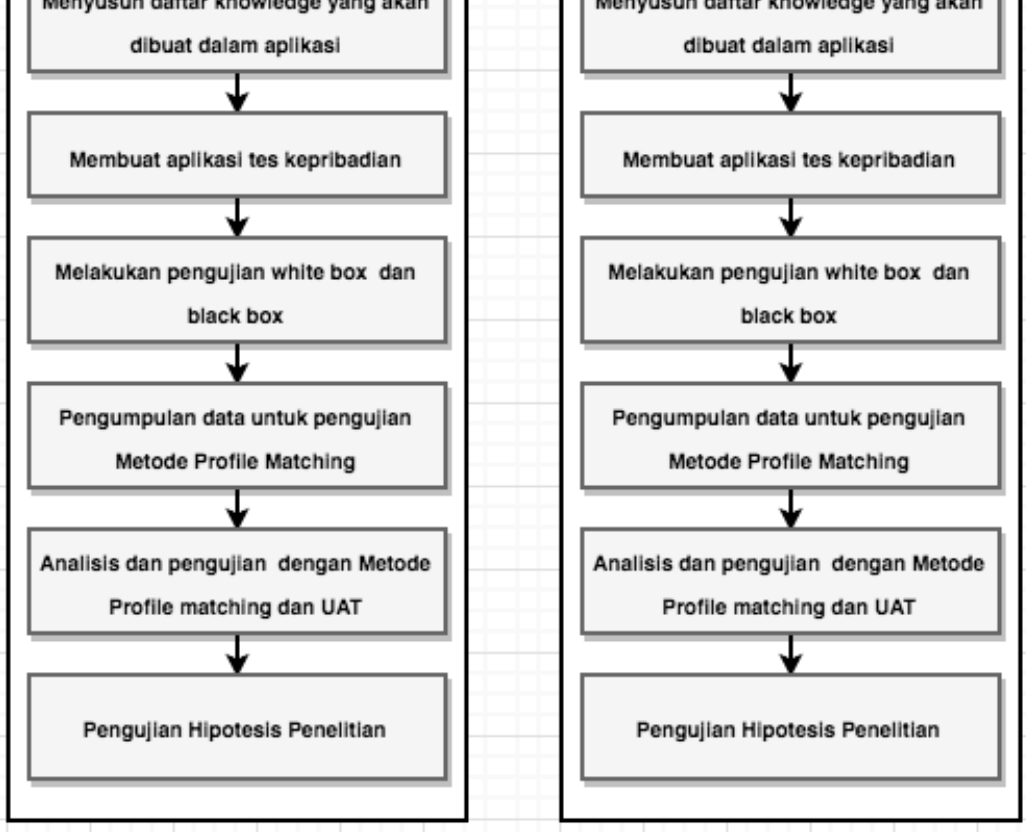

lesign

e research is a research that tests a hypothesis or sults of existing research. The study has a purpose

for the steps taken by researchers in conducting

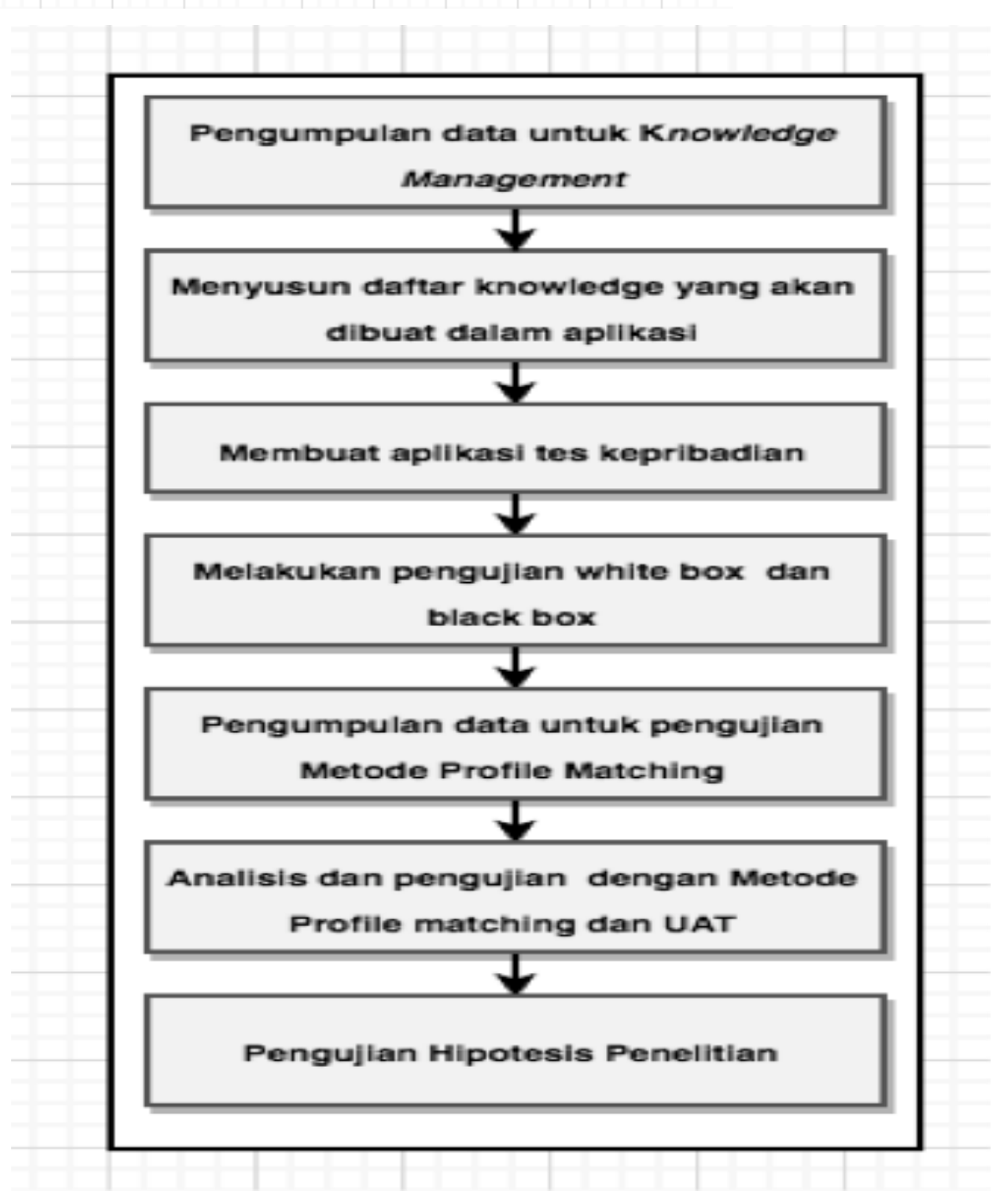

Picture 3.1. Research Step

The research steps taken by the researchers are as follows:

1. Data collection to make applications is done by giving a questionnaire to HRD to find out what knowledge is needed in making the application.

2. After that the author searches for knowledge from various sources to compile the knowledge needed in the application.

3. Then the author makes an application based on the Luther-Sutopo development method. With the stages of Concept, Design,

Material Collecting, Assembly, Testing.

4. For testing the level of compatibility, the writer analyzes using the profile matching method. 
5. After the application is complete, User Acceptance Test or UAT is done to find out the application is suitable and can be accepted by the user well.

6. From the results of UAT testing, hypothesis testing can be done to find out whether the hypothesis can be accepted or rejected.

\section{Research Results}

\subsection{Calculation with Profile Matching Method}

The following are the steps done to calculate the weight of criteria:

1. The first step in determining the selection of the best candidates based on the desired criteria is as follows:

Table 4.1 Criteria, weights and standard values

\begin{tabular}{|l|c|c|c|c|}
\hline Kode_kriteria & Nama_kriteria & Jenis & Bobot & Nilai_standar \\
\hline K1 & Profil & Core Factor & $40 \%$ & 5 \\
\hline K2 & Pengalaman kerja & Core Factor & $10 \%$ & 3.5 \\
\hline K3 & Pendidikan & Core Factor & $10 \%$ & 3.5 \\
\hline K4 & Jurusan pendidikan & Core Factor & $10 \%$ & 5 \\
\hline K5 & Tes Aku & $\begin{array}{c}\text { Secondary } \\
\text { Factor }\end{array}$ & $10 \%$ & 5 \\
\hline K6 & Tes Gali talenta & $\begin{array}{c}\text { Secondary } \\
\text { Factor }\end{array}$ & $10 \%$ & 5 \\
\hline K7 & Tes Toss Dulu & $\begin{array}{c}\text { Secondary } \\
\text { Factor }\end{array}$ & $10 \%$ & 5 \\
\hline K8 & Tes Tebak Bentuk & $\begin{array}{c}\text { Secondary } \\
\text { Factor }\end{array}$ & $10 \%$ & 2.5 \\
\hline K9 & Tes Dinamika Emosi & $\begin{array}{c}\text { Secondary } \\
\text { Factor }\end{array}$ & $10 \%$ & 5 \\
\hline
\end{tabular}

The table above shows that decision making gives weight to each criteria name, while the weights for Core Factor and Secondary Factor are as follows:

a. Core Factor $=50 \%$

b. Secondary Factor $=50 \%$

Table 4.2 Data analysis

\begin{tabular}{|l|c|c|c|c|c|}
\hline No & Nama & K1 & K2 & K3 & K4 \\
\hline 1 & Aldila & $\begin{array}{c}\text { Laki-laki } \\
(28 \text { thn })\end{array}$ & 6 thn & S1 & Engineering \\
\hline 2 & Gita oktarina & Perempuan (30 thn) & 8 thn & S2 & $\begin{array}{c}\text { Marketing } \\
\text { Bisnis }\end{array}$ \\
\hline 3 & Frans Evan & Laki-laki (24 thn) & 1 thn & D3 & HRM \\
\hline 4 & Galih Pangestu & Laki-laki (24 thn) & 1 thn & S1 & IT \\
\hline 5 & Vicky Safitri & Perempuan (25 thn) & 2 thn & SMA & - \\
\hline 6 & Retno Putri & Perempuan (24 thn) & 1 thn & SMA & - \\
\hline 7 & Mauliana Suhada & Perempuan (23 thn) & 1 thn & S1 & Komunikasi \\
\hline 8 & Karina Auyrn & Perempuan (24 thn) & 1 thn & S1 & Sosiologi \\
\hline 9 & Vira Vania & Perempuan (24 thn) & 1 thn & S1 & Bisnis \\
\hline 10 & Alam Setiawan & Laki-laki (24 thn) & 1 thn & S1 & IT \\
\hline
\end{tabular}

The table above shows each criterion, namely gender, age, work experience, education level and education majors. The names that appear from the table data above are candidates who have applied at random jobs. So that the total studied as objects by the author is 10 candidates or participants.

Table 4.3 Weighting

\begin{tabular}{|l|c|c|c|c|c|c|c|c|c|c|}
\hline No & Nama & K1 & $\mathbf{K} 2$ & $\mathbf{K 3}$ & $\mathbf{K} 4$ & $\mathbf{K 5}$ & $\mathbf{K 6}$ & $\mathbf{K} 7$ & $\mathbf{K} 8$ & $\mathbf{K} 9$ \\
\hline 1 & Aldila & 5 & 3.5 & 5 & 0 & 5 & 5 & 5 & 4.5 & 5 \\
\hline 2 & Gita oktarina & 5 & 3.5 & 5 & 5 & 5 & 0 & 5 & 2 & 5 \\
\hline 3 & Frans Evan & 5 & 3 & 3 & 0 & 0 & 5 & 0 & 5 & 0 \\
\hline 4 & Galih Pangestu & 5 & 1 & 3 & 0 & 0 & 5 & 5 & 5 & 0 \\
\hline 5 & Vicky Safitri & 5 & 2 & 4 & 0 & 0 & 0 & 0 & 2 & 0 \\
\hline 6 & Retno Putri & 5 & 1 & 3 & 0 & 5 & 0 & 5 & 2 & 0 \\
& Anjasmoro & & & & & & & & & \\
\hline 7 & Mauliana Suhada & 5 & 1 & 3 & 0 & 5 & 0 & 0 & 4 & 0 \\
\hline 8 & Karina Auyrn & 5 & 1 & 3 & 0 & 0 & 0 & 0 & 4 & 5 \\
\hline 9 & Vira Vania & 5 & 1 & 3 & 0 & 5 & 0 & 0 & 2 & 5 \\
\hline 10 & Alam Setiawan & 5 & 1 & 3 & 0 & 0 & 5 & 0 & 4 & 0 \\
\hline
\end{tabular}


In the next stage is the stage of determining the GAP from the standard value, while the standard values obtained and agreed upon in the search for candidates are $[\mathrm{K} 1=5 ; \mathrm{K} 2=3.5 ; \mathrm{K} 3=3.5 ; \mathrm{K} 4=5 \mathrm{~K} 5=5 ; \mathrm{K} 6=5 ; \mathrm{K} 7=5 ; \mathrm{K} 8=2.5 ; \mathrm{K} 9=5 ;]$ so that it matches the table below:

Table 4.4 GAP

\begin{tabular}{|l|c|c|c|c|c|c|c|c|c|c|}
\hline No & Nama & K1 & K2 & K3 & K4 & K5 & K6 & K7 & K8 & K9 \\
\hline 1 & Aldila & 0 & 0 & 1.5 & -5 & 0 & 0 & 0 & 2.5 & 0 \\
\hline 2 & Gita oktarina & 0 & 0 & 1.5 & 0 & 0 & -5 & 0 & -0.5 & 0 \\
\hline 3 & Frans Evan & 0 & 0.5 & -0.5 & -5 & -5 & 0 & -5 & 2.5 & -5 \\
\hline 4 & Galih Pangestu & 0 & -2.5 & -0.5 & -5 & -5 & 0 & 0 & -2.5 & -5 \\
\hline 5 & Vicky Safitri & 0 & -1.5 & -1 & -5 & -5 & -5 & -5 & 2 & -5 \\
\hline 6 & Retno Putri & 0 & -2.5 & -0.5 & -5 & -5 & -5 & 0 & -0.5 & -5 \\
& Anjasmoro & & & & & & & & & \\
\hline 7 & Mauliana Suhada & 0 & -2.5 & -0.5 & -5 & 0 & -5 & -5 & 1.5 & -5 \\
\hline 8 & Karina Auym & 0 & -2.5 & -0.5 & -5 & -5 & -5 & -5 & 1.5 & 0 \\
\hline 9 & Vira Vania & 0 & -2.5 & -0.5 & 0 & 0 & -5 & -5 & -0.5 & 0 \\
\hline 10 & Alam Setiawan & 0 & -2.5 & -0.5 & -5 & -5 & 0 & -5 & 1.5 & -5 \\
\hline
\end{tabular}

The table above shows the results of GAP which can be seen from the weight of the candidate - the standard value desired by the user. Profile Gap Mapping.

GAP $=$ Candidate profile - Standard profile

Then the results of the conversion value based on the glossy weight of the gap is obtained, the results are obtained as shown below:

Table 4.5 Normalization

\begin{tabular}{|l|c|c|c|c|c|c|c|c|c|c|}
\hline No & Nama & K1 & K2 & K3 & K4 & K5 & K6 & K7 & K8 & K9 \\
\hline 1 & Aldila & 5 & 5 & 3.5 & 1 & 5 & 5 & 5 & 2.5 & 5 \\
\hline 2 & Gita oktarina & 5 & 5 & 3.5 & 5 & 5 & 1 & 5 & 4 & 5 \\
\hline 3 & Frans Evan & 5 & 4.5 & 4 & 1 & 1 & 5 & 1 & 2.5 & 1 \\
\hline 4 & Galih Pangestu & 5 & 2 & 4 & 1 & 1 & 5 & 5 & 2 & 1 \\
\hline 5 & Vicky Safitri & 5 & 3 & 4 & 1 & 1 & 1 & 1 & 3.5 & 1 \\
\hline 6 & Retno Putri & 5 & 2 & 4 & 1 & 1 & 1 & 5 & 4 & 1 \\
& Anjasmoro & & & & & & & & & \\
\hline 7 & Mauliana Suhada & 5 & 2 & 4 & 1 & 5 & 1 & 1 & 3.5 & 1 \\
\hline 8 & Karina Auym & 5 & 2 & 4 & 1 & 1 & 1 & 1 & 3.5 & 5 \\
\hline 9 & Vira Vania & 5 & 2 & 4 & 5 & 5 & 1 & 1 & 4 & 5 \\
\hline 10 & Alam Setiawan & 5 & 2 & 4 & 1 & 1 & 5 & 1 & 3.5 & 1 \\
\hline
\end{tabular}

Then the normalization factor is sought by observing which are included in the core and secondary in all criteria. If, already classifying the data, the average value for the core factor (NCF) value and the value of the secondary factor (NSF) are calculated: 
Table 4.6 Ranking

\begin{tabular}{|l|c|c|c|c|c|c|c|c|c|c|c|c|c|}
\hline \multirow{2}{*}{ No } & Nama & \multicolumn{3}{|c|}{ Core Factor } & \multicolumn{5}{|c|}{ Secondary Factor } & NC & NS & Total \\
\cline { 3 - 11 } & & K1 & K2 & K3 & K4 & K5 & K6 & K7 & K8 & K9 & F & F & \\
\hline 1 & Aldila & 5 & 5 & 3.5 & 1 & 5 & 5 & 5 & 2.5 & 5 & 3.6 & 4.5 & 4.05 \\
\hline 2 & Gita oktarina & 5 & 5 & 3.5 & 5 & 5 & 1 & 5 & 4 & 5 & 4.6 & 4 & 4.30 \\
\hline 3 & Frans Evan & 5 & 4.5 & 4 & 1 & 1 & 5 & 1 & 2.5 & 1 & 3.6 & 2.1 & 2.85 \\
\hline 4 & Galih Pangestu & 5 & 2 & 4 & 1 & 1 & 5 & 5 & 2 & 1 & 3 & 2.8 & 2.90 \\
\hline 5 & Vicky Safitri & 5 & 3 & 4 & 1 & 1 & 1 & 1 & 3.5 & 1 & 3.2 & 1.5 & 2.35 \\
\hline 6 & Retno Putri & 5 & 2 & 4 & 1 & 1 & 1 & 5 & 4 & 1 & 3 & 2.4 & 2.70 \\
& Anjasmoro & & & & & & & & & & & & \\
\hline 7 & Mauliana Suhada & 5 & 2 & 4 & 1 & 5 & 1 & 1 & 3.5 & 1 & 3 & 2.3 & 2.65 \\
\hline 8 & Karina Auyrn & 5 & 2 & 4 & 1 & 1 & 1 & 1 & 3.5 & 5 & 3 & 2.3 & 2.65 \\
\hline 9 & Vira Vania & 5 & 2 & 4 & 5 & 5 & 1 & 1 & 4 & 5 & 4 & 3.2 & 3.60 \\
\hline 10 & Alam Setiawan & 5 & 2 & 4 & 1 & 1 & 5 & 1 & 3.5 & 1 & 3 & 2.7 & 2.85 \\
\hline
\end{tabular}

After the NCF and NSF values are obtained from the average Core factor value and secondary factor, then the total value obtained from $(50 \% \mathrm{X} \mathrm{NCF}$ value $+50 \% \mathrm{X} \mathrm{NSF}$ value) is obtained by the total results which can later be sorted or sorted from the total value of the most high towards the lowest total value like the table below:

Table 4.7 Results

\begin{tabular}{|l|c|l|l|}
\hline No & Nama & Total & Peringkat \\
\hline 1 & Aldila & 4.05 & 2 \\
\hline 2 & Gita oktarina & 4.30 & 1 \\
\hline 3 & Frans Evan & 2.85 & 5 \\
\hline 4 & Galih Pangestu & 2.90 & 4 \\
\hline 5 & Vicky Safitri & 2.35 & 8 \\
\hline 6 & $\begin{array}{c}\text { Retno Putri } \\
\text { Anjasmoro }\end{array}$ & 2.70 & 6 \\
\hline 7 & Mauliana Suhada & 2.65 & 7 \\
\hline 8 & Karina Auyrn & 2.65 & 7 \\
\hline 9 & Vira Vania & 3.60 & 3 \\
\hline 10 & Alam Setiawan & 2.85 & 5 \\
\hline
\end{tabular}

\subsection{Implementation}

Implementation is the process of implementing the new system created. The next step is the creation of an application using Html and Php, and using the Symfony framework. The following is the result of designing the application interface.

1. Dashboard page

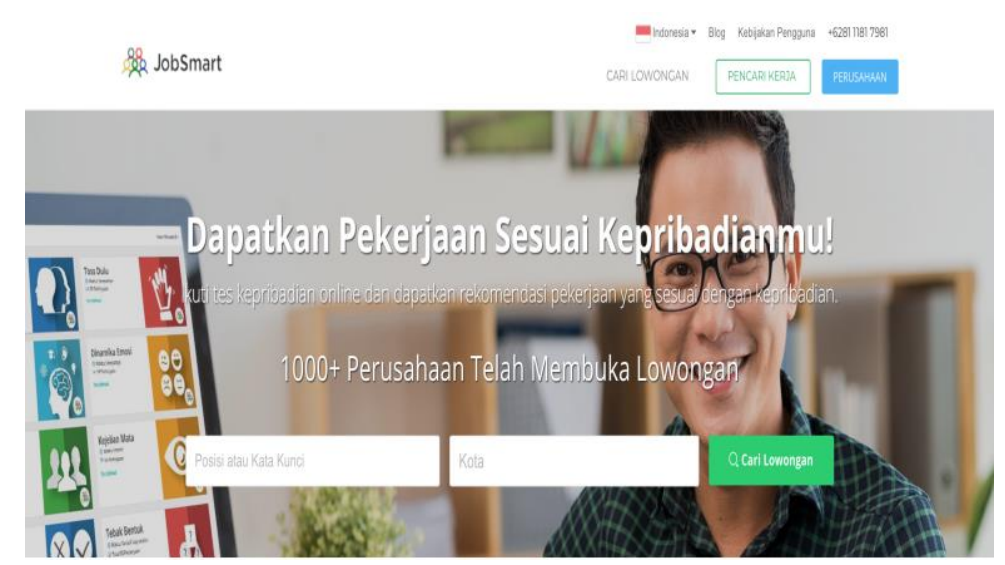

Picture 4.1 Dashboard page

www.scirj.org

(C) 2019, Scientific Research Journal

http://dx.doi.org/10.31364/SCIRJ/v7.i1.2019.P0119608 
On the start page, will display some information to attract visitors and find out some information about jobsmart itself.

2. Login Page
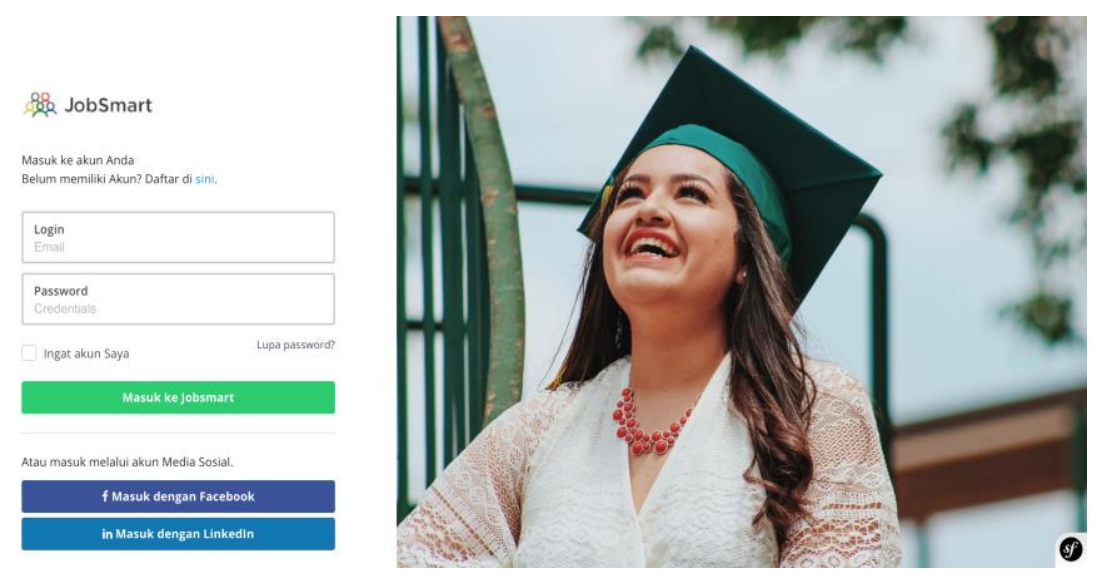

Picture 4.2 Login page

On the login menu page there is an input column in the form of e-mail and password. The entry button will go to the main menu in the application.

3. Result page

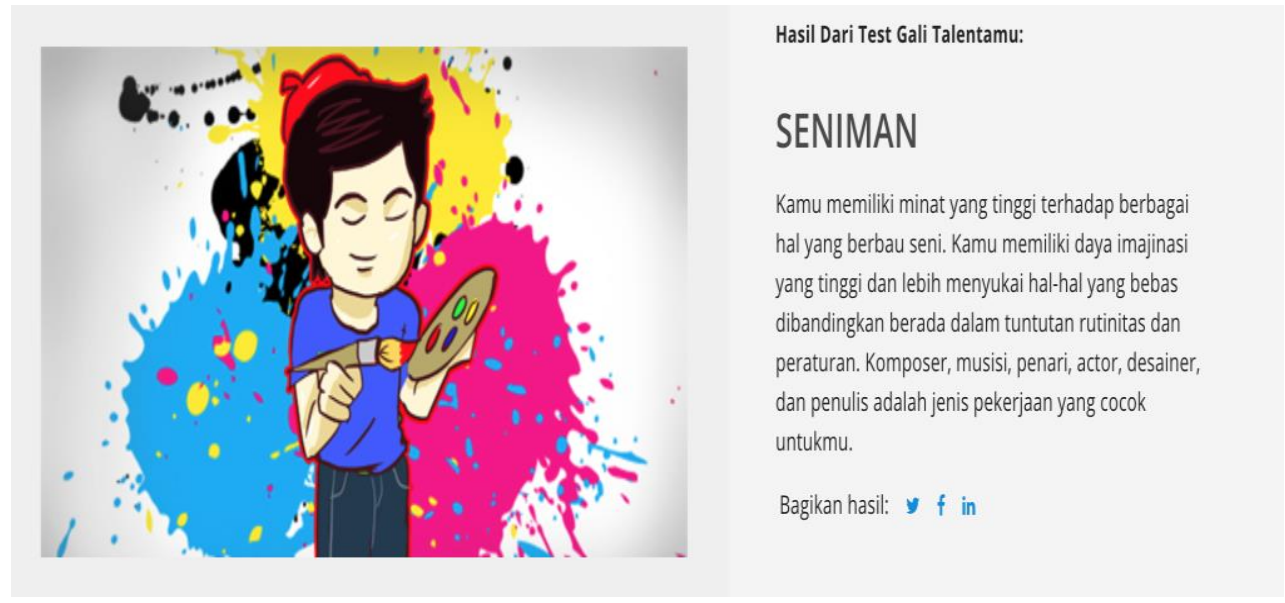

Picture 4.3 Result page

This page is a talent test results page which is a description of test results that reflect the talents or preferences of candidates in doing something related to his hobby.

4. Settings page 


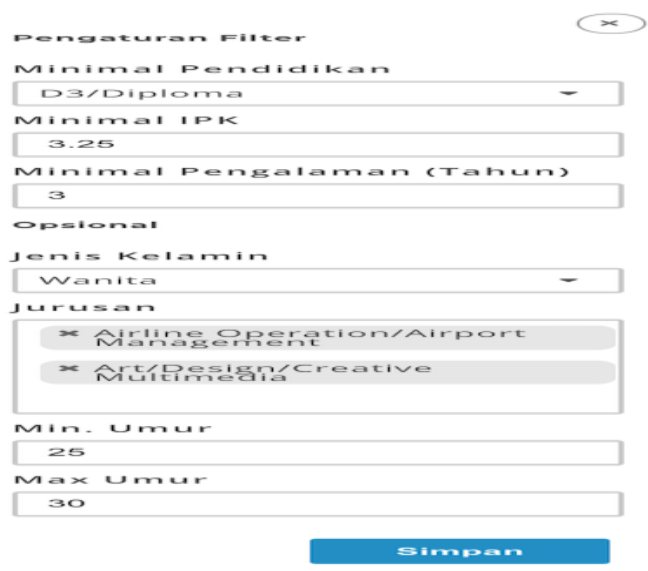

Picture 4.4 Settings page

This page is a settings page for users to make arrangements in search of candidates according to the desired criteria.

5. List candidate page

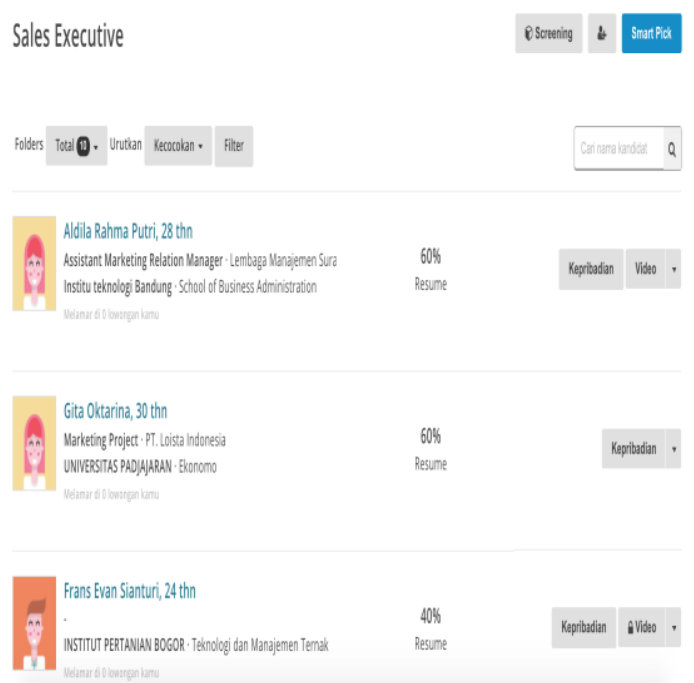

Picture 4.5 List Candidate page

On the candidate list page, users can view the candidate profile briefly, the level of compatibility of the resume and the level of personality suitability.

6. Matching result page

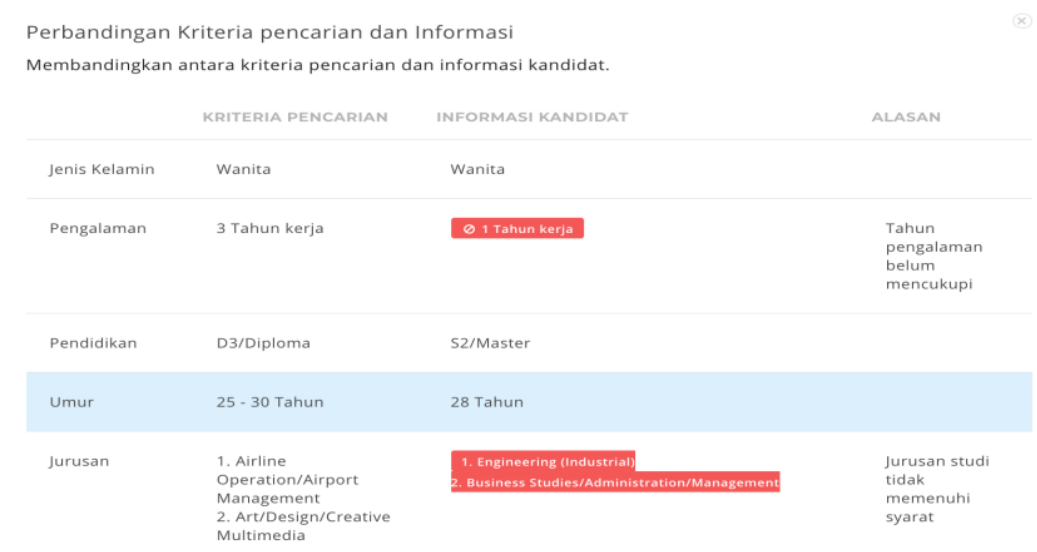


Picture 4.6 Matching result page

There is a page that contains information about the results of the candidate's match with the criteria desired by the user so that the user can see in more detail the incompatibility of the candidate with the desired criteria.

\subsection{System Quality Testing Result}

Table 4.7 System Quality Testing

\begin{tabular}{|c|c|c|c|c|c|c|c|}
\hline No & Pertanyaan & $\mathbf{A}$ & B & $\mathbf{C}$ & $\mathbf{D}$ & $\mathbf{E}$ & Total \\
\hline 1 & $\begin{array}{l}\text { Apakah tampilan prototype } \\
\text { Sistem pendukung } \\
\text { keputusan pemilihan kerja } \\
\text { di Jobsmart Indonesia ini } \\
\text { mudah dipahami? }\end{array}$ & $\mathbf{O}$ & 4 & 6 & 52 & 20 & 82 \\
\hline 2 & $\begin{array}{lr}\begin{array}{l}\text { Apakah } \\
\text { prototype }\end{array} & \text { menu-menu } \\
\text { pendukung } & \text { Sistem } \\
\text { pemilihan kerja di Jobsmant } & \text { keputusan } \\
\text { Indonesia ini r mudah } \\
\text { dipahami? }\end{array}$ & $\mathbf{O}$ & 0 & 9 & 40 & 35 & 84 \\
\hline 3 & 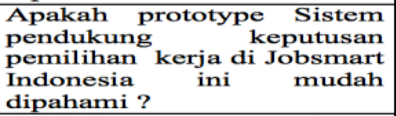 & $\mathbf{O}$ & 2 & 6 & 60 & 10 & 78 \\
\hline 4 & $\begin{array}{l}\text { Apakah prototype sistem } \\
\text { pendukung keputusan } \\
\text { pemilihan kerja di Jobsmart } \\
\text { indonesia mempermudah } \\
\text { mendapatkan informasi } \\
\text { yang berhubungan dengan } \\
\text { proses pemilihan kerja dari } \\
\text { semua komponen penilai? }\end{array}$ & 0 & $\mathrm{O}$ & 9 & 52 & 20 & 81 \\
\hline
\end{tabular}

Based on the above percentage, it can be concluded that the average total number of the percentage is $77 \%$ with good criteria. So that the job selection decision support system at jobsmart can be accepted and used by the user well.

\section{Conclusion and Suggestion}

\subsection{Conclusion}

Then from the matching analysis with the Profile Matching method conclusions are obtained:

1. Helping in finding the best employee candidates from all available candidates can be selected better employee candidates.

2. There are applications that can help support decisions on candidate search recommendations.

3. Assist in accelerating the decision-making process and finding candidates in the current recruitment process.

From these results it can be concluded that the user accepts the m-learning system because of the perceived usefulness and convenience after use.

\subsection{Suggestion}

There are several things that can be improved in future research so that it can produce better, namely:

1. Research Implications

a. Use of other methods in making applications to get better results and add material and other features in order to provide more benefits.

b. Develop a system so that it runs on various mobile devices with different operating systems.

2. Implementation Plan

a. Can be implemented on children's activities at home as a new form of learning method.

b. Using an Android-based smartphone device such as a tablet with a larger screen that affects the convenience of using the application.

\section{References}

Ahmad Chusairi, Juda Damanik. (2014). life span development, perkembangan masa hidup. Jakarta: Erlangga, 95-98. 
Apfia, T. Billy. (2017).Pengangguran di Indonesia, tribunnews.com (diakses 26 Maret 2018).

Kusrini, M.kom. (2007). Konsep dan Aplikasi Sistem Pendukung Keputusan, Yogyakarta: Andi.

Mulyanto, Agus. (2009). Sistem Informasi Konsep \& Aplikasi, Yogyakarta: Pustaka Pelajar.

Pohan, Husni Iskandar. (2007). Pengantar Perancangan Sistem, Jakarta: Erlangga.

Sangkala. Knowledge Management, Jakarta: Rajawali Press.

Santoso, Singgih. (2007) Structural Equation Moedling, Konsep dan Aplikasi dengan AMOS, Jakarta: Elex Media Komputindo.

Sarastiana. (2012). Siklus Manajemen Pengetahuan, sarastiana.blog.ugm.ac.id (diakses 1 Maret 2018).

Sawono, Jonathan dan Umi, Narimawati. (2007). Structural Equation Modeling (SEM) menggunakan LISREL, Yogyakarta: Gava Media.

Shanks. (2012). Black Box testing, kaisarshanks.blogspot.co.id (diakses 21 Maret 2018 